to the enticements of those who would make him a cult-figure in the field of public administration. He was repelled by both, and too busy to bother with either. ...

Fritz Mosher was a truly kind and caring man. ... . He made a difference and a mark on all who knew and worked with him. We are grateful for being so enriched and blessed.

The family suggests that memorial gifts may be made to the MosherAppleby Fund, Maxwell School, Syracuse University, or to the White Burkett Miller Center for Public Affairs, University of Virginia.

Paul T. David

Professor Emeritus

University of Virginia

\section{Donald Winston Smithburg}

Donald Winston Smithburg died May 2, 1990, in Albuquerque, New Mexico. He was Professor Emeritus in the Division of Public Administration at the University of New Mexico. He is survived by his wife, Mary McAnlis Smithburg, a son, Donald R. Smithburg, and a daughter, Laura Smithburg Byrne. Professor Smithburg was born in Seattle, Washington, on May 9 ,
1916. He received a A.B. degree in political science from the University of Washington in 1937. Later he did graduate work at both the University of Washington and the University of Minnesota, and in 1951 he was granted a Ph.D. degree in political science and public administration from Harvard University.

During his career, Smithburg served in a variety of governmental and academic positions. From 1942 to 1945 , he was a Procedures Analyst with the U.S. Government in Washington, D.C. From 1946 to 1967, he was at the Illinois Institute of Technology in Chicago, advancing from instructor to professor in the department of political and social science, and serving as chairman of the department from 1961 to 1964. During these years, he was visiting lecturer at various times at the University of Chicago and Northwestern University, hosted a weekly interview program on NBC-TV Chicago called "The American Scene," and served as consultant to the Chicago Home Rule Commission. With Herbert A. Simon and Victor A. Thompson, he co-authored the classic textbook, Public Administration, published in 1950 and still in print.

From 1967 to 1972 , he was with the department of political science at the University of Alabama in Huntsville, where he served as department chairman, director of the masters program in administrative science, and director of the division of social and behavioral sciences. He was also Consultant on Organization to the Army Missile Command at Redstone Arsenal in Huntsville.

Professor Smithburg was at the University of New Mexico from 1972 until his retirement in 1981, first as visiting professor and then as professor of public administration. As professor emeritus, he continued to teach occasionally until prevented by failing health. He also served a term as president of the New Mexico Chapter of the American Society for Public Administration. He will be remembered by his colleagues as an engaging and faithful friend, by his students as an experienced and knowledgeable teacher, and by the academic community as a well known contributor to his field of study.

Ferrel Heady

Professor Emeritus

University of New Mexico 